\title{
Polish sea ports and the Green Port concept
}

\author{
Aneta Oniszczuk-Jastrząbek ${ }^{1, ~}{ }^{*}$, Barbara Pawłowska ${ }^{1}$, and Ernest Czermański $^{1}$ \\ ${ }^{1}$ University of Gdańsk, Faculty of Economics, 119/121 Armii Krajowej St., 81-824 Sopot, Poland
}

\begin{abstract}
Recently, the focus of action for port authorities has been to find a set of development and investment measures which would, on one hand, ensure the expected technical and organizational conditions for port operations in the future and, on the other hand, incorporate a variety of social and environmental aspects necessary to maintain or improve the quality delivered in these two areas. This set of measures that has been of particular importance to the port industry in the last years is termed the Green Port, as a way of distinguishing it from the previous measures, which were equally intensive but failed to consider the requirements of sustainable growth. The term is used to refer to a port which takes planned investment actions to ensure compliance in all the three areas: economy, society and environment. In Poland, the notion of 'Green Ports' is still in its infancy. The purpose of this paper is to present research into sustainable growth awareness and attitudes in Polish ports. The research was carried out with representatives of Polish sea port authorities to allow identifying the actions for the development of green ports and defining the directions to be adopted in the sea ports development strategies.
\end{abstract}

\section{Introduction}

Transport has been a catalyst for economic development for centuries for Europe. Sea transport allows trade exchange between the European Union (EU) and between the EU group and the rest of the world, being the main carrier of European imports and exports [1]. Maritime transport enterprises are an important source of employment and income for the European economy. According to the European Commission, the "Blue" economy generates 5.4 million jobs and gross added value reaching almost EUR 500 billion annually [2]. The "blue growth" is a long-term strategy to support sustainable development in the entire maritime sector. It draws attention to the fact that seas and oceans are a driving force of the European economy and have great potential for innovation and growth [3]. The activities of the Integrated Maritime Policy help the EU achieve the objectives of the Europe 2020 strategy for smart, sustainable and socially inclusive growth [4].

Innovations across all sectors of the blue economy are crucial for realizing its growth and jobs potential. Innovations can also bring about significant environmental benefits. Ports as a key element of the maritime sector are introducing a new paradigm into their operational strategies with innovations and exponential developments in technology, demography, economy, and society [5]. Global trends and challenges have a significant impact on the port and its operations. They ask for reflection and agility. Given the ongoing

\footnotetext{
*Corresponding author: ekoao@ug.edu.pl
} 
industrial restructuring towards renewable energy and circularity to fight against greenhouse gases and other external effects, ports need to adapt in order to survive and hold on to thousands of jobs and the added value that is created in the port area. This requires well informed strategic decision making.

One of the directions of activities undertaken by port authorities that has been gaining momentum in recent times has been to determine such a set of development activities and investments which would on the one hand provide the expected technical and organizational condition for future port operations, while on the other hand, would take into account various social and environmental requirements to maintain or improve the level of quality of these two areas. The aim of the article is to present the research on the level of awareness and behaviour of Polish ports in the field of sustaining the development, and the Green Port concept in particular. A hypothesis has been formulated that the introduction of the Green Port concept to the development strategy of Polish sea ports will improve their environmental relations and will support the competitiveness of Polish sea ports in the Baltic Sea region. The survey results will allow identifying the directions of activities for the development of green ports and undertaking research to construct a package of instruments that will support these activities. Thus, it will be possible to target the development strategies of Polish sea ports in line with the Green Port concept.

\section{Environmental impacts of maritime transport activities}

According the well-known definition for sustainable development published in the Brundtland report in 1987: sustainable development is development that meets the needs of the present without compromising the ability of future generations to meet their own needs [6]. The balance between social, economic and environmental considerations is the basis for sustainable development. Each area is on the same level of importance. In the port case the social scope often relates to elements such as contribution to direct and indirect employment, interaction and relationship between the port and the city, the contribution to the development of knowledge and education, and the "liveability" of the area surrounding the port. From an economic perspective, return on investment is vital in the assessment of any development projects. In addition, efficiency of the use of the port area and the provision of facilities for companies in order to maximize their performance, are all significant economic considerations. The environmental dimension relates to environmental performance and management.

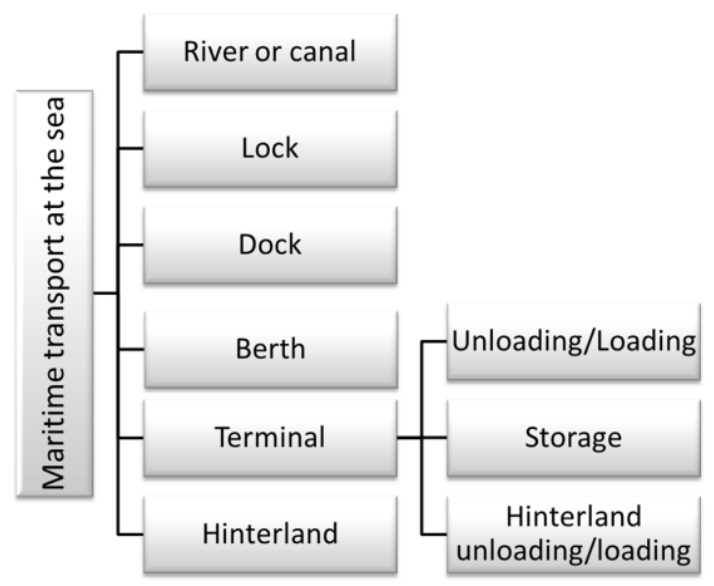

Fig. 1. Decomposition of maritime transportation activities [7]. 
In the last years public concerns regarding the environmental impacts of maritime transport have been increasing. This is due to the fact that despite the better environmental performance of this mode of transport with respect to other modes, its overall impacts will be outweighed by the expected increase in the volume of ship movements. The assessment of maritime transport environmental impacts with respect to other modes of transportation is a challenging task, since these impacts are not entailed only by navigation but are dependent on a number of activities carried out in ports (see Fig. 1. above).

The environmental effects of ports may be direct, i.e. taking place in the port area, or indirect, as a result of ship movements or the use of other types of vehicles in an intermodal transport chain. The environmental impact of ports may thus be divided into three subcategories [8]:

- problems caused by port activity itself,

- problems caused at sea by ships calling at the port,

- emissions from inter-modal transport chains serving the port hinterland.

Table 1. Impacts due to maritime transport activities, including illegal activities and accidental events [9].

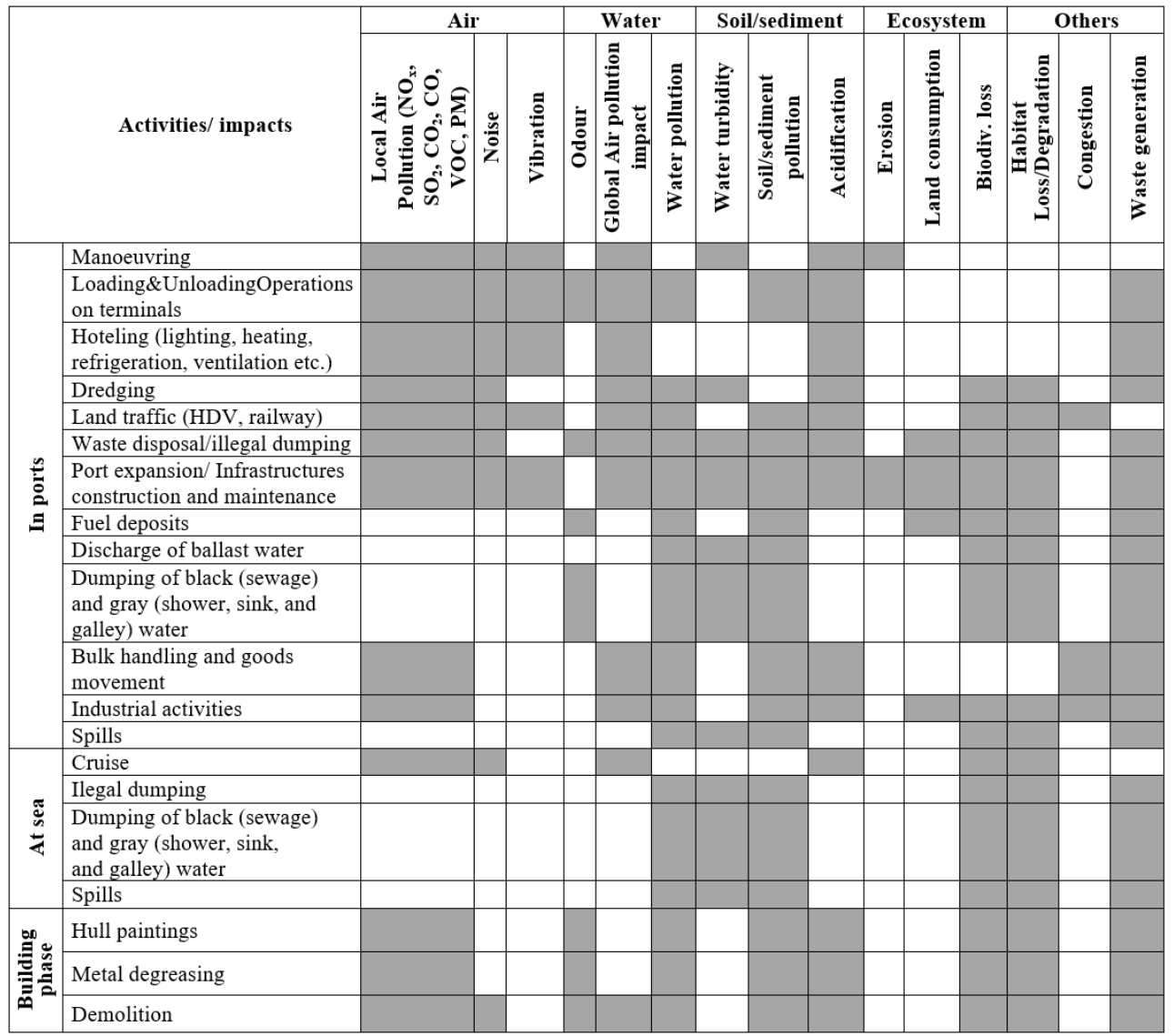

The impacts of maritime transport should be analyzed by considering different receptors (air, water, soil, ecosystem, society, urban environment and other) or by considering the activities. Each maritime transportation activity occurring in ports, at sea or during ship construction/maintenance/dismantling, presents different environmental impacts. Together with these impacts also those deriving from accidental events or illegal actions have to be 
considered when evaluating the overall contribution of the maritime transportation sector to the environmental quality. The interrelation among environmental impacts and activities/events of the maritime transportation sector are reported in Table 1.

Some of the environmental problems caused by port activities are related to specific types of ships or cargo, but most are generic effects of ship movements and use of auxiliary engines at berth. The environmental impact from loading and unloading and moving goods in the port area differs somewhat between the various types of cargo. The effects of landuse and dredging are more site-specific $[10,11,12]$. The overall environmental impact of ports depends among many other parameters on the type of location. Ports may be situated on rivers or in estuaries, or on a sheltered or an open coast.

\section{Challenges of sea ports in the second decade of the $21^{\text {st }}$ century}

Port authorities around the world face a different set of challenges. Global trade routes migrate towards the Asian continent and cargo flows (of raw materials) from Africa are on the rise. Port authorities in both geographies see a strong demand for increased port efficiency and additional port and terminal capacity, moving away from reliance on exports of fossil resources and developing a market position as central hubs of maritime transport. In Europe and North America, port authorities are working hard on fully automated container terminals, sustainability and alternative business models [13, 14]. Also, port authorities are asked to rethink the viability of inner-city port areas as a result of the increasing size of vessels, dedicated terminal operations and supply chain rationalization[15].

The current fluctuations in worldwide economic growth do not mask the overall marked expansion of international trade or the pivotal role that the port sector plays in the overtly global Logistic Chain. Shipping is vital to the worldwide economy, with around $90 \%$ of world trade being carried by the international shipping industry [14]. According to UNCTAD [16] despite modest improvement in world seaborne trade volumes in 2016, weaker world economic growth, dwindling merchandise trade volumes and rising cost pressures continued to weigh on the performance of world sea ports. While these trends affect all ports, container ports are affected the most. Throughout 2016 and until mid-2017, world container ports continued to deal with the deployment of ever larger ships, cascading of vessels from main trade lanes to secondary routes, growing concentration in liner shipping, heightened consolidation activity, reshuffling of liner shipping alliances and growing cybersecurity threats.

Environmental management is increasingly practiced as an essential component of the strategy of any operation that claims to be sustainable, efficient and compliant with legislation. One of the main challenges identified by the European Sea Ports Organisation (ESPO) in its environmental code [17] was the sustainable development of sea ports. The port may be the cause of environmental impacts in its surrounding area (inside and outside). It is the receptor as well as the emitter of impacts. Environmental issues are of strategic relevance for European ports.

Table 2 presents the top- 10 environmental issues over time as the priorities in the European ports. It is an important review because it identifies the high priority issues common to the sector on which ports are working. Air quality remains at the top of the priorities together with energy consumption. Noise pollution is identified as the third top environmental priority by the European port sector as a whole followed by water quality. The management of port waste remains high within the environmental priorities of the sector. Climate change, enters the top-10 for the first time. The rank of priorities has been 
updated with the results of the 91 responses in 2017 to the EcoPorts SDM (the Self Diagnosis Method) [10].

Table 2. Top 10 environment priorities of the European port sector over time [18, 19].

\begin{tabular}{|c|c|c|c|c|}
\hline & 1996 & 2004 & 2009 & 2017 \\
\hline 1 & $\begin{array}{l}\text { Port development } \\
\text { (water) }\end{array}$ & $\begin{array}{l}\text { Garbage/ port } \\
\text { waste }\end{array}$ & Noise & Air quality \\
\hline 2 & Water quality & $\begin{array}{l}\text { Dredging: } \\
\text { operation }\end{array}$ & Air quality & Energy consumption \\
\hline 3 & Dredging: disposal & Dredging: disposal & Garbage/ port waste & Noise \\
\hline 4 & Dredging: operation & Dust & Dredging: operation & Water quality \\
\hline 5 & Dust & Noise & Dredging: disposal & Dredging: operation \\
\hline 6 & $\begin{array}{l}\text { Port development } \\
\text { (land) }\end{array}$ & Air quality & $\begin{array}{l}\text { Relationship with local } \\
\text { community }\end{array}$ & Garbage/ port waste \\
\hline 7 & Contaminated land & Hazardous cargo & Energy consumption & Port development (land) \\
\hline 8 & $\begin{array}{l}\text { Habitat } \\
\text { loses/degradation }\end{array}$ & Bunkering & Dust & $\begin{array}{l}\text { Relationship with local } \\
\text { community }\end{array}$ \\
\hline 9 & Traffic volume & $\begin{array}{l}\text { Port development } \\
\text { (land) }\end{array}$ & Port development (water) & Ship waste \\
\hline 10 & Industrial effluent & $\begin{array}{l}\text { Ship discharge } \\
\text { (bilge) }\end{array}$ & Port development (land) & Climate change \\
\hline
\end{tabular}

A study conducted by Comtois and Slack [8, 13], based on an analysis of websites of 800 ports and 120 shipping lines from North America, Europe and Asia confirms the importance of the above mentioned priorities. The study indicates that the top five environmental issues mentioned by port authorities are water quality (mentioned by $25 \%$ ), waste disposal (21\%), air quality (19\%), habitat conservation (19\%) and noise (15\%).

EcoPorts is the main environmental initiative of the European port sector. It was initiated by a number of proactive ports in 1997 and has been fully integrated into the European Sea Ports Organisation (ESPO) since 2011. The overarching principle of EcoPorts is to raise awareness on environmental protection through cooperation and sharing of knowledge between ports and improve environmental management [18].

One of the directions for the development of sea ports taking into account the achievement of the priorities presented in Table 2 is the Green Port concept. The term "Green Port" evolved from the research activities related to the sustainability in the context of the maritime industry [18]. A Green Port, also known as an ecological port, is a sustainable development port, which not only meets the environmental requirements, but also raises their social, economic interests. The core question of an ecological port is to find a balance point between environmental, social impacts and economic interests. The economic and social development of ports should not exceed the carrying capacity of the corresponding natural system [11].

The Green Port is defined as a product of the long-term strategy for the sustainable and climate friendly development of the port infrastructure [20]. This concept in a broader sense means responsible behaviour of all working structures, from port management to each individual employee. The concept is to integrate environmentally friendly methods in port activities, operations and management. A Green Port aims at utilizing its resources efficiently, reducing the negative impact on regional environment, raising the environment management level and improving the quality of the natural surroundings of the port area. 
The Green Port concept includes the idea of protecting the environment in all its infrastructure works, in the sustainable development policies that it follows, and in all the activities and operations conducted in the area.

Unfortunately, none of the Polish ports belongs to the EcoPorts network. Therefore, they do not use the good practices implemented within the network. Due to the fact that environmental management has a significant impact on the competitiveness of the port, there is a need to introduce environmental priorities into the port strategies. The conducted questionnaire surveys are aimed at showing the stage of this process in Polish ports and the level of environmental awareness of employees and managers of Polish ports.

\section{Objective and methodology of survey}

The main objective of the survey was to determine the level of awareness of representatives of the ports in Gdańsk, Gdynia and Szczecin-Świnoujście in the area related to the concept of green ports.

On the basis of the organizational structure of each of the ports, a database was created, which covered the upper and medium port management levels and specialists from selected departments dealing with, inter alia, the sustainable development, environmental protection or cooperation with the environment. The persons on the list were then contacted to take part in the survey. Some of these individuals refused to answer the questions giving as the main reason: the lack of time, unwillingness to provide information or lack of knowledge in a given area. For this reason, it was decided to use the purposive sampling in the survey, as a result of which a database was created containing a total of 18 employees selected as those dealing with issues of the sustainable development in the three above-mentioned ports. As a result of the conducted survey, $50 \%, 38 \%$ and $12 \%$ of the responses were received from the Ports of Gdańsk, Szczecin-Świnoujście and Gdynia, respectively. As far as the gender of the respondents was concerned, $55 \%$ of the respondents were female and $45 \%$ male. The age of the respondents was as follows: $5 \%$ of the respondents were in the age bracket (20-25 years), 12\% - (26-30 years), 17\% (31-35 years), 22\% (36-40 years) and $44 \%$ (over 40 years).

The questionnaire survey was conducted in the period from 28 June to 30 July 2018 , using the online questionnaire posted on the website ebadania.pl. By reason of the relatively short duration of the study and the insufficient number of completed questionnaires, the study should be treated as a survey.

The questionnaire used in the survey consisted of fourteen questions, of which four concerned the respondent's details. In the sixth question, a complex attitude scale was used, i.e. a variation of the Likert scale. All the items of the Likert scale were assigned intensity scales, being an interval measuring scale [21, 22, 23].

The scale steps are described in the questionnaire by voice. In this question, the respondents assesses the Green Port operation as "very good", "good", "I have no opinion", "very bad", "bad".

\section{Survey results}

The conducted survey shows that $83 \%$ of the respondents came across the concept of sustainable development (SD). Such results of the survey show high awareness of the concept of sustainable development among the managerial staff in the three studied ports. Then, the respondents were asked a question concerning knowledge of the Green Port concept. As many as $61 \%$ of the respondents answered that they had met with this concept, of which $11 \%$ said they knew exactly what it was about, while $50 \%$ said they did not know 
what it was about. The remaining group of the respondents, i.e. pprox.. 38\% had never encountered the Green Port concept. As many as $94 \%$ of the respondents responded positively to the question regarding the implementation activities associated with the Green Port concept by the Port in which they worked. The rest of the respondents replied that the Port did not undertake any activities related to the implementation of the concept in question and had no knowledge about whether the Port was planning to undertake such activities in the near future or not.

The most frequently mentioned activities in the implementation of the Green Port concept are: minimizing the Port's negative impact on the local environment, community and economy ( $89 \%$ of responses), then including representatives of local communities in the decision making, caring for the quality of air and water (78\%). The benefits for the local community - not only profits, but also better working conditions, access to knowledge and technology, and noise reduction $(67 \%)$ were the issues placed in the third position as far as the number of responses is considered. At a similar level the respondents pointed out to the rational utilization of resources $(11 \%)$. These were followed by the respondents indicating lower energy consumption (50\%), including the interests of the local community in the port development strategy (33\%) and reduction of water pollution by vessels (11\%). At this point it should be noted that the results obtained from the above question to a large extent correspond to the 10 priorities presented in Table 2 . In the study, the respondents ranked the care for the quality of air and water in the second place, while in the study presented in Table 2 the quality of air and water took first and fourth places in 2017, respectively. Subsequent places in the conducted survey were taken by such activities corresponding to the 10 priorities such as noise reduction, energy consumption or relations with the local community. In the conducted survey, the respondents did not mark such activities as reducing port waste, caring for relations of the port with the city and the local community. This may result from the limitations that were applied in the instructions to the following question (it was possible to mark 5 out of the 13 possible answers at a maximum) or the respondents may have considered these three activities as hardly relevant for the Green Port concept.

The next question concerned the respondents' assessment of activities related to the Green Port concept (Fig. 2.).

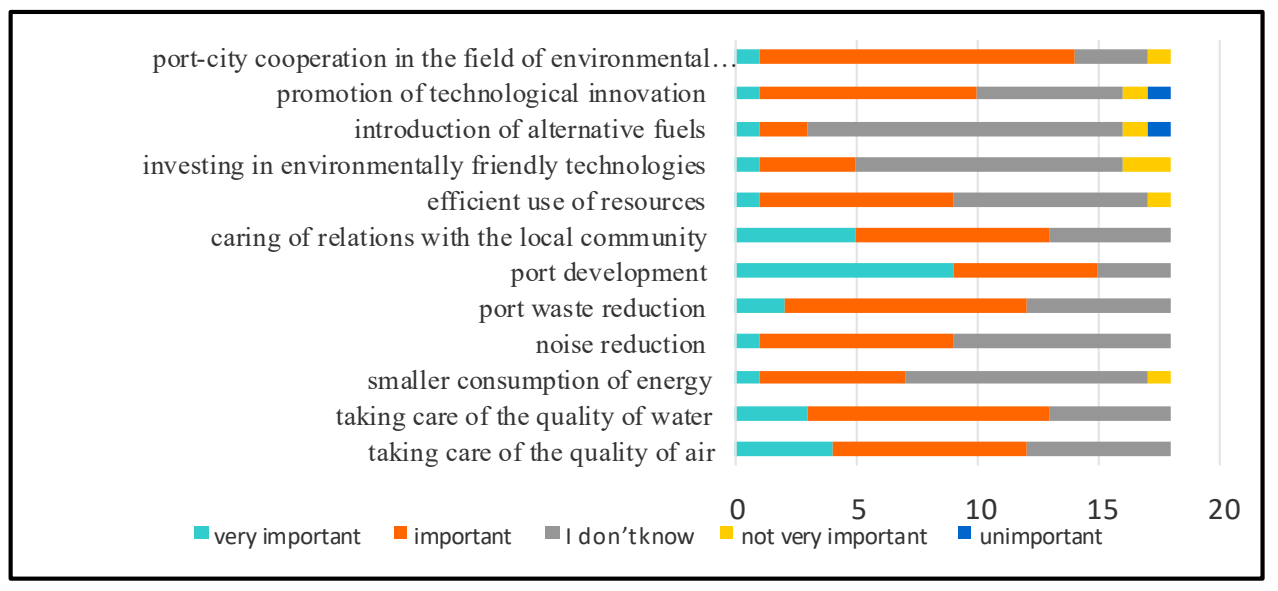

Fig. 2. Assessment of activities undertaken by the Ports of Gdansk, Gdynia and Szczecin-Świnoujście related to the Green Port concept

Fig. 2. shows that the most important area in the average opinion of the surveyed employees of ports related to the Green Port concept is the introduction of alternative fuels 
(2.94), then investing in environmentally friendly technologies (2.78), smaller consumption of energy (2.61). The following places are taken by promotion of technological innovation (2.56), efficient use of resources (2.5) and noise reduction (2.44). The Green Port activities undertaken to the least extent according to the respondents are port waste reduction and port-city cooperation in the field of environmental protection (2.22), taking care of the quality of air an water (2.11) as well as caring of relations with the local community (2.0) and the port development (1.67).

Analyzing the two above-mentioned questions, the conclusion to be drawn is that although the respondents associate the Green Port concept in the first place with minimizing the negative impact on the local environment, community and economy, then including representatives of local communities in decision-making, caring for the quality of air and water, the actions taken in these areas by the surveyed Ports are not very frequent.

Another question asked to the respondents was aimed at identifying the benefits and problems associated with the application of the principles on which the Green Port concept is based in practice, according to the respondents' opinions. The received responses are shown in Fig. 3. and Fig. 4.

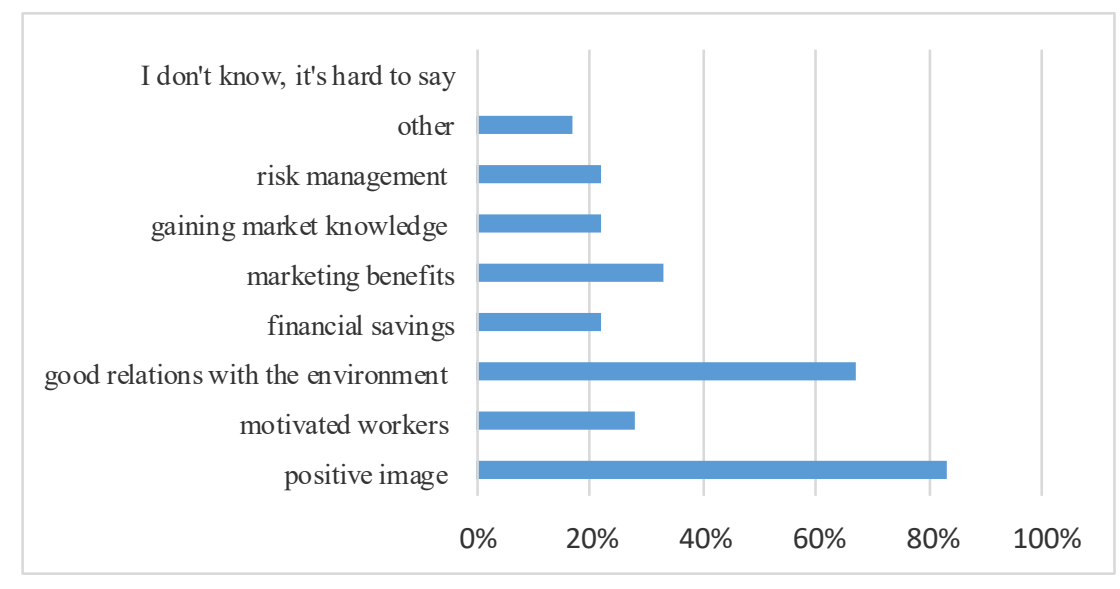

Fig. 3. Benefits from applying the principles of the Green Port concept in the respondents' opinion.

The data presented in Fig. 3 shows that in the respondents' opinion the most important benefits, related to the application of the principles of sustainable development are a positive image $(83 \%)$ and good relations with the environment (67\%), then marketing benefits $(33 \%)$ and motivated workers $(28 \%)$. Equivalent assessments of the respondents were received by financial savings, gaining market knowledge and risk management (22\%).

In addition to the benefits, respondents were asked about problems related to the application of the principles of sustainable development. The most frequent problem was the need to incur financial expenses and the lack of translation into everyday activities (67\% of all responses), followed by the complexity of the issue $(44 \%)$. The lack of knowledge and skills, lack of involvement of the city authorities, lack of financial support from the state $(22 \%)$ and the need to hire a specialist in the field of sustainable development, lack of a long-term vision of maritime policy $(17 \%)$ were mentioned subsequently. The least problem according to respondents is the lack of time and staff (5\%). 


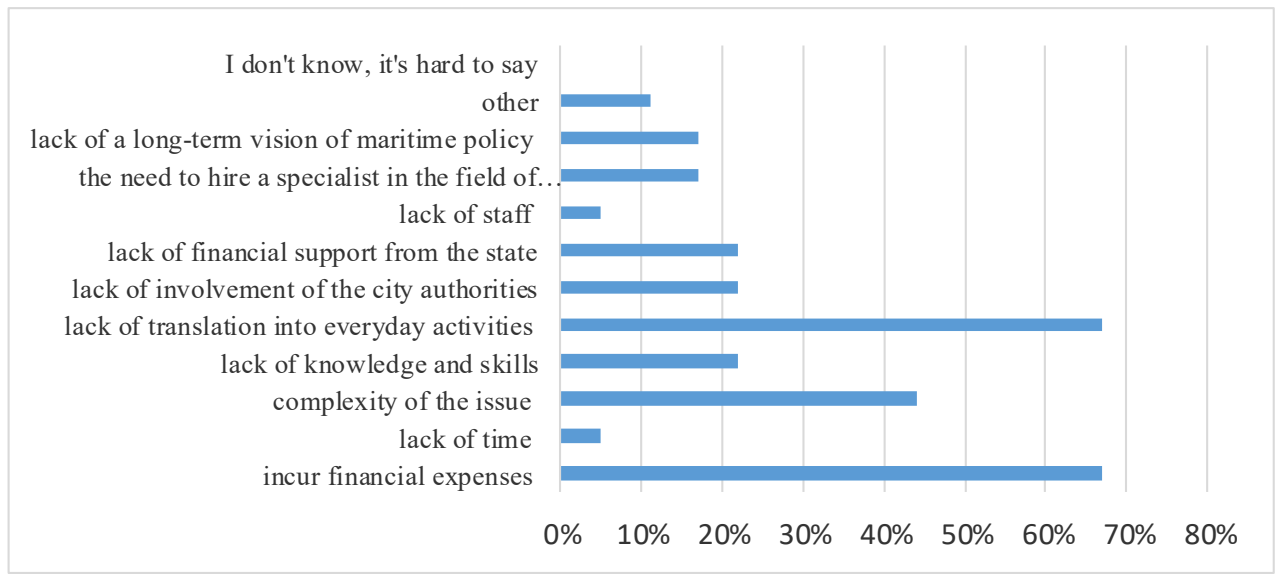

Fig. 4. Problems related to applying the principles of the Green Port concept in the respondents' opinion

Another important issue in the study was the measurement of external effects generated by economic activity. It was only $33 \%$ of the respondents who answered that the port measured external effects of economic activity, while $67 \%$ answered 'I do not know', 'Hard to say'. The question what external effects were measured in the port was answered by the respondents in the following way: noise and water pollution (5 responses), $\mathrm{CO}_{2}$ emissions (4 responses), land pollution ( 3 responses), followed by $\mathrm{SO}_{\mathrm{x}}, \mathrm{NO}_{\mathrm{x}}$ emission, smell/stench (2 responses) and emission of particles $\mathrm{PM}_{\mathrm{x}}$, light emission (1 response).

\section{Conclusions}

Unfortunately, the Polish ports have not joined the EcoPorts initiative, hence, there is no way to compare the actions undertaken by them to those initiated in the network of ports belonging to the initiative. EcoPorts is the main environmental initiative of the European port sector. It was initiated by a number of proactive ports in 1997 and has been fully integrated into the European Sea Ports Organisation (ESPO) since 2011 [24]. The overarching principle of EcoPorts is to raise awareness on environmental protection through cooperation and sharing of knowledge between ports and improve environmental management. As the survey shows, the environmental awareness of ports is high, however, there are no tools that would allow shifting from the level of declaration to the level of activity. For this activity to be effective and efficient, it is necessary to clearly diagnose the status of the port's relations with the environment and to take into account aspects of environmental protection in both operational and investment activities. In line with best business practice, port authorities formulate and periodically update their vision or business plan for the development of the port. In this vision information regarding the trends for sustainability and the environment on the port level should be provided. Port authorities are increasingly more aware that ports are a significant source of emissions and could facilitate the energy transition.

It would be reasonable for the Polish sea ports to join the EcoPorts network. The EcoPorts initiative provides two well-established tools to its members: (1) Self Diagnosis Method (SDM) and (2) Port Environmental Review System (PERS), a certificate assessed by the Lloyds register, These tools fit ports of different sizes and at different stages in the development of their environmental priorities. The application of common indicators to measure the effects of activities towards the implementation of the Green Port concept will 
give the opportunity to assess the effects of these activities and to compare the distance to other ports in this respect.

The comparison of the results of the survey conducted in Polish ports and the results of the latest Ecoports study shows that there are certain significant differences in the priorities and goals of implementing the measures towards the greenification of ports. The assessment of activities aimed towards reducing waste, both generated in the port and by vessels is different. This issue was included among the top 10 priorities of the EcoPorts network, while it remained unnoticed in the study of Polish ports. The issues related to the protection of the quality of air and water as well as elimination of noise were of high importance. The issues of rational energy consumption in Polish ports have been decidedly ranked at lower places than in the Port Environmental Review System of 2017.

The accession of Polish ports to the EcoPorts network would allow carrying out an assessment of the current status and programming activities with the goal to eliminate harmful emissions from port-related sources and companies in the port. Being a part of the network would also allow the ports to benefit from good practices shared by members of the initiative. To obtain such definied goals the ports must incorporate environmental planning into their development plans. Renewable energies, green charging where environmental friendly modes are rewarded, waste management, cyclical economies and biofuels are some of the actions undertaken by ports to spare the environment.

\section{References}

1. A. Zapładka, Zrównoważony transport morski, (Global Compact Network Poland, 2016) http://ungc.org.pl/strefa-wiedzy/zrownowazony-transport-morski-2/

2. Communication from the Commission to the European Parliament, the Council, the European Economic and Social Committee and the Committee of the Regions, Blue Growth - opportunities for marine and maritime sustainable growth, COM 0494 final (2012)

3. The Limassol Declaration, Declaration of the European Ministers responsible for the Integrated Maritime Policy and the European Commission, on a Marine and Maritime Agenda for growth and jobs

https://ec.europa.eu/maritimeaffairs/sites/maritimeaffairs/files/docs/body/limassol_en.pdf

4. Communication from the Commission to the European Parliament, the Council, the European Economic and Social Committee and the Committee of the Regions, Innovation in the Blue Economy: realising the potential of our seas and oceans for jobs and growth, COM 254 final/2 (2014)

5. Report on the Blue Growth Strategy Towards more sustainable growth and jobs in the blue economy, (Commission Staff Working Document, SWD 128 final, 2017)

6. Our common future, (New York, NY: Oxford University Press, WCED, 1987)

7. P. Bickel, M. Jordans, J.C. Martìn, H. Meersman, F. Monteiro, T. Pauwels, C. Román, C. Ruijgrok, N. Sieber, P. Socorro-Quevedo, E. Van de Voorde, T. Vanelslander, A. Voltes-Dorta, Marginal cost case studies for air and water transport, Deliverable 4 of GRACE ( ITS, University of Leeds, Leeds, 2006)

8. N.A. Braathen (Ed.), Environmental Impacts of International Shipping: The Role of Ports (OECD, 2011)

9. A. Miola, V. Paccagnan, I., Mannino, A. Massarutto, A. Perujo, M. Turvani, External costs of Transportation Case study: maritime transport (Joint Research Centre Institute for Environment and Sustainability, EC, 2009) 
10. M. Puig, C. Wooldridge, A. Michail, R.M. Darbra, Environ. Sci. Policy 48, 57-66 (2015)

11. C. Trozzi, R. Vaccaro, Environmental impact of port activities,), [in:] C.A. Brebbia, J. Olivella (Eds.), Maritime Engineering and Ports II (WIT Press, Southampton, 2000)

12. E. Peris-Mora, J.M. Diez Orejas, A. Subirats, S. Ibanez, P. Alvarez, Mar Pollut Bull 50, 1649-1660 (2005)

13. C. Comtois, B. Slack, Restructuring the Maritime Transportation Industry: Global overview of sustainable development practices (Ministère des Transports du Québec, Québec, 2007)

14. Annual Review 2018 - Shaping future of Shipping, http://www.shipping-facts.com/

15. A. Oniszczuk-Jastrząbek, B. Pawłowska, E. Czermański, Sea port as an element of sustainable city on the example of Gdańsk (to be published)

16. Review of Maritime Transport 2017 (New York and Geneva, United Nations, UNCTAD, 2018)

17. Environmental Code of Practice, (ESPO, Brussels, 2003) https://www.espo.be/media/espopublications/ESPOEnvironmentalCodeofPractice2004.pdf

18. Sustainability Report 2017, (EcoPort, 2017) https://www.ecoports.com/publications/sustainability-report-2017

19. Towards excellence in port environmental management and sustainability, Environmental Code of Practice (ESPO, Brussels, 2012)

20. D.S.H. Moon, J.K. Woo, T.G. Kim, Green Ports and Economic Opportunities, [in:] L.L. Froholdt (Ed.), Corporate Social Responsibility in the Maritime Industry (Springer International Publishing AG, Springer Nature, 2018)

21. G. Wieczorkowska, P. Kochański, M. Eljaszuk, Statystyka. Wprowadzenie do analizy danych sondażowych $i$ eksperymentalnych (Wydawnictwo Naukowe Scolar, Warszawa, 2003)

22. A. Sagan, Analiza satysfakcji i lojalności klientów, [in:] Zastosowania statystyki i data mining (StatSoft Polska, Warszawa-Kraków, 2003)

23. A. Oniszczuk-Jastrząbek, Contemporary Economy, Vol. 7, Issue 1 (2016)

24. EcoPorts web page: http://www.ecoports.com/ 